\title{
Update on long-term toxicity of agricultural GMOs tolerant to roundup
}

\author{
Gilles-Eric Seralini * (1)
}

\begin{abstract}
Agricultural genetically modified organisms (GMOs) are plants obtained by gene transfer or more recently by geneediting. Their major common phenotypic trait for which $99 \%$ have been modified is that these are designed to be grown with pesticides, which may bioaccumulate in the plants and/or the consumer, and/or express insecticides in their cells. Examples of both types are Roundup-tolerant soy and corn and Bt insecticidal plants. Recently, Steinberg et al. concluded that there were no adverse effects in rats from consumption of a GM corn tolerant to Roundup, called NK603, and that no other long-term studies are justified. This contradicts several of our in vivo studies on the short- and long-term toxicological effects of either the same GMO, other GMOs, or the pesticide Roundup itself. Our results were attributed in particular to the long-term in vivo effects of Roundup residues, which also present toxic and endocrine-disrupting effects in vitro. These effects were clearly linked to the formulants of the pesticide, such as petroleum residues and heavy metals, and not to glyphosate alone. In fact, the treated rats in Steinberg et al.'s experiment showed many adverse effects, some of which, including increased mortality in males fed GM corn + Roundup, were statistically significant. Other adverse effects affected both treated and control groups. The latter trend may be due to contamination of the feed of the control animals by many carcinogenic pollutants, including pesticides, but also by Roundup residues and Roundup-tolerant GMOs. For instance, glyphosate contained in Roundup was found to be 300-1400 times more elevated in their control feed than in our treated group. In conclusion, Steinberg et al's study is invalidated by the contaminated feed, biased interpretations, and major undeclared conflicts of interest.
\end{abstract}

\section{Introduction}

For over a decade, a scientific and public debate has continued about the assessment of the long-term health and environmental effects of agricultural GMOs (genetically modified organisms) [1]. While this debate has until recently focused on GMOs obtained by transgene insertion, it is now expanding to include more recent genetic engineering techniques, so-called gene-editing techniques (or mutagenesis techniques). All are finally GMOs, and $99 \%$ of those which are cultivated on a large scale share a common phenotype: they have been modified to tolerate an herbicide, such as Roundup-tolerant

*Correspondence: gilles-eric.seralini@unicaen.fr

Department of Biology and Network on Risks, Quality and Sustainable Environment MRSH, University of Caen Normandy, 14032 Caen, France Discussion on Steinberg et al. (2019), https://doi.org/10.1007/s0020 4-019-02400-1. soy, and/or to produce an insecticide, such as Bt corn. This has not changed over the last 25 years [1]. Therefore, a primary and important toxicity question regarding these GMOs is quite straightforward. Do these pesticides and their metabolites have direct or indirect effects on health over the long term? The question of the risks of the genetic modification per se, when not associated with pesticides, appears theoretical, since in real farming conditions these plants are designed to be grown with pesticides and/or to express them in their cells. Pesticides do include herbicides, insecticides, and fungicides.

\section{Background}

In the summer of 2019, the authorization for the consumption of a genetically modified (GM) corn, NK603, engineered for tolerance to Roundup as well as many similar GMOs, was renewed in the European Union. The
Springer Open

C The Author(s) 2020. This article is licensed under a Creative Commons Attribution 4.0 International License, which permits use, sharing adaptation, distribution and reproduction in any medium or format, as long as you give appropriate credit to the original author(s) and the source, provide a link to the Creative Commons licence, and indicate if changes were made. The images or other third party material in this article are included in the article's Creative Commons licence, unless indicated otherwise in a credit line to the material. If material is not included in the article's Creative Commons licence and your intended use is not permitted by statutory regulation or exceeds the permitted use, you will need to obtain permission directly from the copyright holder. To view a copy of this licence, visit http://creativeco mmons.org/licenses/by/4.0/. 
scientific basis for the European Food Safety Authority (EFSA) review lies especially on a new paper by Steinberg et al. [2], which concludes that there are no long-term effects from consumption of this corn.

Back in 2005, we demonstrated the differential toxicity between glyphosate and Roundup (the most widely used herbicide in the world) on human cells. We found that Roundup contained formulants that were 1000 times more toxic than glyphosate, but these were declared as inert and their identity was kept confidential [3]. This has been extensively confirmed in the literature in different models [4]. We then demonstrated that Roundup had a far greater capacity than glyphosate to disrupt hormones at lower non-toxic levels, in vitro [5] and then in vivo over a short-term period in mammalian testes [6]. We progressively characterized by mass spectrometry the undeclared compounds present in Roundup from 2013 to 2018, that were composed of oxidized petroleum residues [7] and heavy metals such as arsenic [8]. The latter compound was declared as pesticide in the past and was banned for this use in the 1970s.

We logically investigated and initially published [9] in 2012 the long-term health effects of this mixture on mammals, using the formulated herbicide Roundup at very low levels comparable to those found contaminating water or food and feed, in particular through the consumption of Roundup-tolerant GMOs. This class of GMOs represents by far most cultivated agricultural GMOs (80\%), without the GM plants being only insecticidal and not herbicide-tolerant.

Since then, some internal mails from Monsanto Company (the company responsible for testing and first commercializing the herbicide and the GM corn NK603, now owned by Bayer), were obtained as a result of US cancer litigation and are included in the so-called Monsanto Papers [10, 11]. The emails demonstrated that Monsanto knew at least since 2000 that the glyphosate-only assessment-as practised in regulatory evaluations worldwide-was not enough to determine possible adverse effects on the health of humans, animals and the environment. The emails further demonstrated that since 2005 Monsanto has attempted to destroy my team's work and reputation, in particular by recruiting third-party, supposedly independent experts at the highest levels to voice ghost-written and biased arguments (Henry Miller or Wallace Hayes, for instance [10-12]), who did not, however, publicly disclose their links with Monsanto. This is highly linked to the discovery of the formulants toxicity present in Roundup or Roundup-tolerant GMOs. The defamation campaign reached a peak in 2012 after we first published a study demonstrating the long-term effects of Roundup at
$0.1 \mathrm{ppb}$ and of a Roundup-tolerant GMO, NK603 corn, both sprayed with Roundup and unsprayed, in rats. The study found that breast tumours and disorders of the sex hormones were related to the consumption of this pesticide, like other important liver and kidney diseases [9].

The paper was retracted 1 year later by the journal's Editor-in-Chief, Wallace Hayes, for the highly unusual-indeed, unprecedented-reason of "inconclusiveness". Hayes admitted that no fraud or errors were found in the paper $[13,14]$. It subsequently emerged from the Monsanto Papers that Hayes had a contractual relationship with Monsanto, which he failed to declare [10, 11]. Moreover, Richard Goodman who had assessed the same GM corn for Monsanto became an assistant of the Editor-in-Chief for that purpose [12].

Scientific arguments defending our work were subsequently published in the same journal in 2013 [15]. Consequently, the study itself was republished in 2014 [16] in Environmental Sciences Europe. Moreover, the long-term effects of Roundup identified in the original study (administered over a 2-year period in drinking water at $0.1 \mathrm{ppb}$ ), namely toxicity to the kidney and liver, were more recently confirmed by transcriptomic, proteomic, and metabolomic analyses [17, 18]. Breast tumours and disorders of the sex hormones are related to the consumption of this pesticide according to our work [16]. Metabolic disruptions were evidenced in the same GMO [19]. Despite all these new confirmations, however, criticisms of our work continue to be organized and ghost-written by Monsanto [10, 11].

While science progresses through questioning, criticism, and further experiments, the controversy that resulted from Monsanto's scientifically unjustified campaign never was meant to contribute to the scientific process by pushing the border of knowledge forward. It was solely designed to confuse and mislead regulators to ignore our research and to authorize this class of GMOs for release into the food and feed supply chain.

In this context, to supposedly reassess our work, on February 12, 2019, a paper was published [2] that concluded that Monsanto's GM corn NK603 had no harmful effects on Wistar rats. Certain media outlets rushed to affirm that our studies demonstrating the corn's toxicity were thereby proven false [20].

The question of how GMOs and pesticides are assessed for safety by regulators in countries around the globe is still a matter of intense debate. Controversy has also arisen over the patents attached to GM food plants and the dependence of GM herbicide-tolerant crops on applications of synthetic pesticides, which are also products of the same petrochemical and biotechnology industry [21]. 


\section{Decryption}

Almost 7 years after our research showed Roundup and Roundup-tolerant GM corn to be toxic, we welcomed the intention of a detailed study inspired by half of our work, which is quoted in the first few words of the summary of Steinberg et al. [2]. "Half of our work", because the testing of long-term effects of Roundup alone at environmental levels $(0.1 \mathrm{ppb})$ on a diet without pesticides was not accomplished nor tested in Steinberg et al's work, in contrast with ours, as indicated by these authors. GMOs treated with Roundup were tested as feed in comparison to controls, which we also did, but with the opposite results. The goal of this discussion is to analyse the reasons for the discrepancies in results, especially because these are the only two long-term feeding studies on this matter. Steinberg et al. used a different rat strain called Wistar Han RCC versus Sprague-Dawley used by Seralini et al. [16] and, notably, by Monsanto in their 90-day rat feeding study which first allowed the authorization of consumption in the world [22]. The Wistar Han rat is considered less sensitive than the Sprague-Dawley strain, without real proof. Steinberg et al. [2] also used a larger number of animals, as is suited for a carcinogenicity study. In contrast, we followed a long-term toxicity protocol. Our retracted and republished rat study $[9,16]$ was originally not even meant to be a cancer study; this was indicated in the paper. Therefore, the experimental design and number of rats was consistent to OECD 452 when it began in 2008; at this time the 1981 norms were routinely used; although there was no guidelines for GMOs, we had to adapt and improve these [15]. However, as tumours were developing at higher rates in the treatment groups, we were required to report this as an indicator for other serious effects that must be followed up. Steinberg et al. [2] also benefited from far more funding than our pioneering study.

\section{The serious deficiencies of Steinberg's protocol:} glyphosate-based residues at high levels everywhere, even in controls when studying a glyphosate-tolerant GMO

With regard to GM maize, there was a control group with supposedly no GM feed in the Steinberg study, another group fed GMO corn unsprayed with Roundup, and a group fed GMO corn sprayed with Roundup, but the feed made from these plants, as well as the control group feed, were all contaminated with $30-140 \mathrm{ppb}$ of this pesticide (i.e. $\mu \mathrm{g} / \mathrm{kg}$, corresponding to 300-1400 times more of glyphosate and thus the other Roundup residues than the levels we found to be toxic in our study [16]. This is explained in Steinberg et al's paper (in [2] discussion, 1st column, 2nd paragraph), as well as in another publication from the same group, specifically on the contamination of their feed [23, 24]. This increases the background level of serious diseases in the controls, preventing any specific observable effect of the GMO treatment on animals.

Given such neglect of the contamination issue, we would have stopped there instead of drawing scientifically inadequate conclusions. The glyphosate contamination was due probably to a mix with another transgenic plant tolerant to Roundup, such as soybean or rapeseed. But Steinberg et al. [2] continued with their long-term toxicity study with that contaminated diet. They consider that the glyphosate detected "has no harmful effect" (discussion, 1st column, 2nd paragraph) since "It shows no genotoxic or carcinogenic potential in mice and rats", according to EFSA. This could be considered as biased and selective citing of non-experimental opinions from EFSA. However, this agency of the European Union was compromised on this issue, according to several investigations that led to resignations [25]. The debate is still ongoing between supporters of the World Health Organization's International Agency for Research on Cancer (IARC), which declared glyphosate a possible carcinogen [26], and supporters of other regulatory agencies, including EFSA and the European Chemicals Agency (ECHA), which stated that it does not pose a carcinogenic risk.

\section{A second serious mistake: many other carcinogenic compounds in controls masking any long-term observable effect of the treatment}

In addition, the oxidized petroleum residues [7] and arsenic and other heavy metals formulants found in Roundup [8] must be taken into consideration, because these are by themselves carcinogenic and endocrine disruptors. This is a serious and inexcusable gap in the scientific assessment, which gives rise to a major methodological and interpretive bias.

Steinberg et al. [2] also confuse the terms glyphosate and Roundup, while we have identified from 2013 to 2018 the presence of toxic residues alongside glyphosate [7, 8]. Moreover, the rat feed in Steinberg et al's experiment contained 70-290 ppb arsenic/fresh weight arsenic [23, 24], suggesting that all animal groups were subjected to its chronic toxicity. This by itself may mask the possible effects of the studied GMO over the long term.

Steinberg et al's control diets, as well as the treatment diets, were contaminated with many other pollutants (results, end of 1st column [2]): dioxins and furans, PCBs, PAHs, mycotoxins and nitrosamines in "low and similar" amounts [23]. All diets also contain pesticides: 2-phenylphenol, cypermethrin, deltamethrin, tetramethrin, ethoxyquin, piperonyl butoxide, pirimiphosmethyl, N-desethyl-pirimiphos-methyl and propiconazole, and glyphosate, as well as the glyphosate metabolite AMPA. As they are supposed to be below the regulatory limits (which we have repeatedly 
indicated to be inadequate [4] since these were never tested in long-term studies with the toxic formulations of pesticides), "they could not affect the health of rats in any way", according to the authors (results, 2nd column, 1st paragraph [2]). But this assertion can be ruled out by experts on this domain since combined effects of mixtures, as well as endocrine and carcinogenic effects, are all possible from these contaminants [27], which are effectively observed in their controls.

This contamination and the justification given in the paper [2] are therefore, scientifically not acceptable. In order to avoid such problems, in our study, we fed the control animals with plants specially grown without pesticides, using organic farming methods. This is the correct way to study and compare the effect of a pesticide or a GMO that contains a pesticide in the diet of the treated group. These organic methods have been proven to yield crops that test negative for pesticides in comparison to pesticide-treated neighbouring ones [28].

In 2015, we published a study [29] showing the heavy contamination of commercial laboratory animal feeds with pesticides and many other pollutants even in regulatory experiments. We concluded that tumours that arise in animals fed such diets cannot be assumed to be "spontaneous" or naturally occurring. We had 5-8 times fewer tumours and diseases in our pesticide-free control rats than did Steinberg et al. [2]. This key finding could be explained by the lack of contaminants in our diets, which were therefore able to highlight any effects from the GMO and/or the Roundup. It is also important to use a rat strain susceptible to tumours because Homo sapiens is also highly susceptible to cancer. However, the differential sensitivity between the different rat strains is not so obvious if all the chemical contaminants are not carefully measured in their environment and diets.

\section{A third serious mistake: many other glyphosate-tolerant GMOs and others in controls}

The contamination of the foods of Steinberg's control diets does not stop there. They contain GM corn NK603, albeit in "non-quantifiable" traces (Results [2], "Feed composition analysis"), which are supposed to "not influence the feeding trials in any way". However, no evidence is presented to support this assumption. Steinberg et al.s diets also contain many other types of GMO, as they admit in their raw data (various GMOs and their associated pesticides contaminate commercial laboratory animal feeds, as explained above).

This highlights the negligence in the production of the diets. The presence in the diets of numerous contaminants biases the experiment towards finding "no effect" from the test substances.

\section{The results from Steinberg et al.: major biases and subjective interpretations}

In fact, many rats, including in the control and treated groups in Steinberg et al's experiment had tumours and cancers in various organs after 2 years. According to the authors, they arose spontaneously, and comparably in all groups, but for us they could be explained by the contamination of their feed. Their very high level may mask any treatment-related effect.

No research was done on the chronology of the appearance of the tumours or their size compared with controls, contrary to our experiment. The chronology of mortality was not studied. Steinberg et al. studied two different doses of the GMO, whereas we studied three. When only two doses are studied, no dose-related effect can be investigated.

The authors considered a priori that all the feed contaminations would have no effect. This is only their subjective opinion, and many indications that we have cited can prove the contrary.

\section{High mortality rates in males fed GM NK603 corn}

In spite of the many weaknesses of the study design, Steinberg et al. [2] still found significant differences, most notably in male mortality, which was higher in the animals fed the GM corn sprayed with Roundup for 2 years (Table 12).

In addition, increased incidence of pituitary neoplasia, and disorders of the sex hormones estradiol and thyroid in females were also noticed by them (discussion [2]). We also showed such differences many years ago in Seralini et al. [12, 16]. Steinberg et al. dismissed these effects as "not... adverse" due to the lack of histopathological alterations in the estrogen-sensitive tissues and organs. However, lesions can be missed in the histopathological sectioning, and/or some functional alterations that have biological effects on the organism may not result in histopathological changes. It is not the place of Steinberg et al. to dismiss such changes based on assumptions, like EFSA or industry conclude, particularly in a research study conducted with the aim of revealing any health risk to humans. Moreover, the histopathological sections are not shown even in supplementary data [24], and thus cannot be analysed by others to confirm or refute the interpretation of Steinberg et al.

Steinberg et al. dismiss some statistically significant differences in treatment groups as not biologically relevant since they are "small" or "not dose-related", the latter meaning there should be an effect proportional to 
the dose of the GMO. However, such assertions are not scientifically justifiable [29]. A dose-related observation begins with three doses and not two according to OECD. Moreover, an effect that is statistically significant should not be dismissed as "small" and the effects of hormone disruptors are often not proportional to the dose.

In order to dismiss the differences, the authors compare the effects observed in this experiment with the "historical control data" obtained from the previous feeding trials conducted under the related GRACE program or others. This use of unrelated historical control data violates the Test Guidelines of the Organisation for Economic Cooperation and Development (OECD) on the conduct and design of chronic toxicity and carcinogenicity studies [30]-guidelines that Steinberg et al. cite in their paper. The OECD states, "the concurrent control group is always the most important consideration" when considering the effects of the treatment under test.

We also oppose such lax approaches, which can only lead to the underestimation of potential toxicological effects. All differences must be carefully considered, and a precautionary approach taken, which favours the investigation rather than neglect of risks, since this is the last stage of biosafety research before mass consumption by animal and human populations. No clinical trials are made for food.

Surprisingly, the authors finally conclude from all this that we should no longer bother to conduct long-term studies on agricultural GMOs in general, which is contrary to the spirit of scientific inquiry and (more importantly) is not supported by the concerning results that were found in spite of the methodological weakness of the study. We strongly disagree, even if it is the same reasoning for Monsanto, industry and EFSA that has allowed commercial release on this basis.

\section{Serious undeclared conflicts of interests at many levels}

Pablo Steinberg declares that he has no conflict of interests in the article he publishes on these results and their interpretations, which we have revealed as very lax, in accordance with Monsanto's practices that we had counter-appraised and published [31].

However, his published paper mentions that he subcontracted some of the analyses to the Covance Laboratory in Madison, Wisconsin, USA, in which Monsanto has invested and performed many studies with the same GMO and others. These studies [22] had previously shown bias, which we previously documented in detail [32-35].

In addition, Steinberg noted that he was an expert for the International Life Science Institute (ILSI) in his declaration of interest on another public document for
G-TwYST, the acronym for this experiment [2]. ILSI was chaired by Monsanto and it is well known as an industryfunded lobbying organization [36] which has worked to weaken regulation and testing, including of GMOs and pesticides, and is supportive of their use [37].

Pablo Steinberg also sat on the BfR Committee; i.e. the German risk assessment agency responsible for the evaluation of glyphosate. This agency copy-pasted whole passages of the evaluation written by Monsanto and has come under severe scrutiny because of this practice [38].

We also note that Pablo Steinberg has been (and is still) an adviser, since 2005, to the Danone Institute. The group of the same name is a member of ILSI. The publication of our 2012 study motivated Steinberg's work because we found many risks for this GMO and Roundup. But is now proven, thanks to the Monsanto Papers, that as soon as our study was published, a senior member of the Danone group coordinated the contacts between Monsanto and the French government [39] that led the latter not to take our research into account at the regulatory level. If our research had been considered, it would have provoked a ban on GM NK603 corn and Roundup. Danone has molecular biology laboratories that produce genetically modified microorganisms for yogurts and other products. Monsanto has subsequently carried out an until then unprecedented defamation campaign against us, through a "scientific community" constructed by and consisting of ILSI members and other long-time industry-aligned scientists or influenced by these ones. These facts were revealed in the seven libel suits that we brought and won against these lobbies from 2011 to 2017 [40].

For all these reasons, the findings and conclusions of Steinberg et al.s study [2] are unreliable, and the paper should be retracted, and the results deleted from regulatory appraisals and risk assessments.

\section{Abbreviations}

ECHA: European CHemicals Agency; EFSA: European Food Safety Authority; GM: Genetically modified; GMO: Genetically modified organism; IARC : International Agency for Research on Cancer; ILSI: International Life Science Institute; OECD: Organisation for Economic Cooperation and Development; $\mathrm{PAH}$ : Polycyclic aromatic hydrocarbon; PCB: Polychlorinated biphenyls.

\section{Acknowledgements}

Not applicable.

\section{Authors' contributions}

There is only one author responsible for this discussion. The author read and approved the final manuscript.

\section{Author's information}

The author was expert for the French Government and the European Union as well as for different countries on GMOs health risks, he conducted numerous researches on pesticides and GMOs since 30 years. 


\section{Funding}

There was no specific funding for this work.

\section{Availability of data and materials}

All raw data are available on the websites of the journals.

\section{Ethics approval and consent to participate}

Not applicable.

\section{Consent for publication}

Not applicable.

\section{Competing interests}

The authors declare that they have no competing interests.

Received: 24 August 2019 Accepted: 24 January 2020

Published online: 11 February 2020

\section{References}

1. Seralini GE, Mesnage R, Clair E, Gress S, Spiroux de Vendômois J, Cellier D (2011) Genetically modified crops safety assessments: present limits and possible improvements. Environ Sci Eur 23:10. https://doi org/10.1186/2190-4715-23-10

2. Steinberg P, Van der Voet H, Goedhart PW, Kleter G, Kok EJ, Pla M, Nadal A et al (2019) Lack of adverse effects in subchronic and chronic toxicity/ carcinogenicity studies on the glyphosate-resistant genetically modified maize NK603 in Wistar Han RCC rats. Arch Toxicol 93:1095-1139. https:// doi.org/10.1007/s00204-019-02400-1

3. Richard S, Moslemi S, Sipahutar H, Benachour N, Seralini GE (2005) Differential effects of glyphosate and Roundup on human placental cells and aromatase. Environ Health Perspect 113:716-720. https://doi. org/10.1289/ehp.7728

4. Mesnage R, Defarge N, Spiroux de Vendômois J, Seralini GE (2015) Potential toxic effects of glyphosate and its commercial formulations below regulatory limits. Food Chem Tox 84:133-153. https://doi.org/10.1016/j. fct.2015.08.012

5. Gasnier C, Dumont C, Benachour N, Clair E, Chagnon MC, Seralini GE (2009) Glyphosate-based herbicides are toxic and endocrine disruptors in human cell lines. Toxicology 262:184-191. https://doi.org/10.1016/j. tox.2009.06.006

6. Cassault-Meyer E, Gress S, Seralini GE, Galeraud-Denis I (2014) An acute exposure to glyphosate-based herbicide alters aromatase levels in testis and sperm nuclear quality. Environ Toxicol Pharmacol 38:131-140. https ://doi.org/10.1016/j.etap.2014.05.007

7. Mesnage R, Bernay B, Seralini GE (2013) Ethoxylated adjuvants of glyphosate-based herbicides are active principles of human cell toxicity. Toxicology 313:122-128. https://doi.org/10.1016/j.tox.2012.09.006

8. Defarge N, Spiroux de Vendômois J, Seralini GE (2018) Toxicity of formulants and heavy metals in glyphosate-based herbicides and other pesticides. Toxicol Rep 5:156-163. https://doi.org/10.1016/j.toxrep.2017.12.025

9. Seralini GE, Clair E, Mesnage R, Gress S, Defarge N, Malatesta M, Hennequin D, Spiroux de Vendômois J (2012) Retracted: long term toxicity of a Roundup herbicide and a Roundup-tolerant genetically modified maize. Food Chem Tox 50:4221-4231. https://doi.org/10.1016/j.fct.2012.08.005

10. Baum Hedlund Aristei Goldman (2019) Monsanto Papers. https://www. baumhedlundlaw.com/toxic-tort-law/monsanto-roundup-lawsuit/monsa nto-secret-documents/. Accessed 13 Aug 2019

11. U.S. Right to Know (2019) Monsanto Papers. https://usrtk.org/monsantopapers/. Accessed 13 Aug 2019

12. Novotny E (2018) Retraction by corruption: the 2012 Seralini paper. J Biol Phys Chem 18:32-56. https://doi.org/10.4024/19NO17F.jbpc.18.01

13. Retraction notice of Seralini GE et al. (2014) Food Chem Tox 63:244. https ://doi.org/10.1016/j.fct.2013.11.047

14. Seralini GE, Mesnage R, Defarge N (2014) Conclusiveness of toxicity data and double standards. Food Chem Tox 69:357-359. https://doi. org/10.1016/j.fct.2014.04.018

15. Seralini GE, Mesnage R, Defarge N, Gress S, Hennequin D, Clair E, Malatesta M, Spiroux de Vendômois J (2013) Answers to critics: why there is a long term toxicity due to a Roundup-tolerant genetically modified maize and to a Roundup herbicide. Food Chem Tox 53:476-483. https://doi. org/10.1016/j.fct.2012.11.007

16. Seralini GE, Clair E, Mesnage R, Gress S, Defarge N, Malatesta M, Hennequin D, Spiroux de Vendômois J (2014) Republished study: long-term toxicity of a Roundup herbicide and a Roundup-tolerant genetically modified maize. Environ Sci Eur 26:14. https://doi.org/10.1186/s1230 2-014-0014-5

17. Mesnage R, Arno M, Costanzo M, Malatesta M, Seralini GE, Antoniou MN (2015) Transcriptome profile analysis reflects rat liver and kidney damage following chronic ultra-low dose Roundup exposure. Environ Health 14:70. https://doi.org/10.1186/s12940-015-0056-1

18. Mesnage R, Renney G, Seralini GE, Ward M, Antoniou MN (2017) Multiomics reveal non-alcoholic fatty liver disease in rats following chronic exposure to an ultra-low dose of Roundup herbicide. Sci Rep 7:39328. https://doi.org/10.1038/srep39328

19. Mesnage R, Agapito-Tenfen SZ, Vilperte V, Renney G, Ward M, Seralini GE, Nodari RO, Antoniou MN (2016) An integrated multi-omics analysis of the NK603 Roundup-tolerant GM maize reveals metabolism disturbances caused by the transformation process. Sci Rep 6:37855. https://doi. org/10.1038/srep37855

20. Foucart S (2018) OGM: six ans après «l'affaire Seralini » une étude conclut à l'absence de toxicité sur les rats. Le Monde 13 Dec. https://www.lemon de.fr/planete/article/2018/12/13/toxicite-des-mais-transgeniquesune-etude-d-ampleur-conclut-a-l-absence-d-effets-sur-les-rats_53966 81_3244.html. Accessed 20 Nov 2019

21. Seralini GE, Douzelet J (2017) The great health scam. Natraj Publishers, New Delhi

22. Hammond B, Dudek R, Lemen J, Nemeth M (2004) Results of a 13 week safety assurance study with rats fed grain from glyphosate tolerant corn. Food Chem Tox 42:1003-1014. https://doi.org/10.1016/j.fct.2004.02.013

23. Chereau S, Rogowsly P, Laporte B, Coumoul X, Moing A, Priymenko N, Steinberg P, Wilhelm R, Schiemann J, Salles B, Richard-Forget F (2018) Rat feeding trials: a comprehensive assessment of contaminants in both genetically modified maize and resulting pellets. Food Chem Tox 121:573-582. https://doi.org/10.1016/j.fct.2018.09.049

24. Supplementary material Steinberg et al. (2019) https://www.cadima.info/ index.php/area/selectStudy/15Analysisplantmeterials/diets. Accessed 14 Aug 2019

25. Corporate Europe Observatory (2019) Appendix. https://corporateeurope .org/en/efsa/2016/03/conflicts-interest-european-food-safety-authorityenough-enough. Accessed 14 Aug 2019

26. IARC (2015) Monograph on pesticides. https://www.iarc.fr/wp-content/ uploads/2018/07/MonographVolume112-1.pdf. Accessed 14 Aug 2019

27. Hernández AF, Gil F, Lacasaña M (2017) Toxicological interactions of pesticide mixtures: an update. Arch Toxicol. 91:3211-3223. https://doi. org/10.1007/s00204-017-2043-5

28. Seralini GE, Douzelet J (2017) The taste of pesticides in wines. Food Nutr J. https://doi.org/10.29011/2575-7091.100061

29. Mesnage R, Defarge N, Rocque LM, Spiroux de Vendômois J, Seralini GE (2015) Laboratory rodent diets contain toxic levels of environmental contaminants: implications for regulatory tests. PLoS ONE 10(7):e0128429. https://doi.org/10.1371/journal.pone.0128429

30. Organisation for Economic Co-Operation and Development (2019) Guidelines 451, 452. https://www.oecd-ilibrary.org/environment/guida nce-document-116-on-the-conduct-and-design-of-chronic-toxic ity-and-carcinogenicity-studies-supporting-test-guidelines-451-452-and453_9789264221475-en. Accessed Aug 142019

31. Seralini GE, Mesnage R, Defarge N, Spiroux de Vendômois J (2014) Conflicts of interests, confidentiality and censorship in health risk assessment: the example of an herbicide and a GMO. Environ Sci Eur 26:13. https:// doi.org/10.1186/s12302-014-0013-6

32. Seralini GE, Spiroux de Vendômois J, Cellier D, Sultan C, Buiatti M, Gallagher L, Antoniou M, Dronamraju KR (2009) How subchronic and chronic health effects can be neglected for GMOs, pesticides or chemicals. Int J Biol Sci 5:438-443. https://doi.org/10.7150/ijbs.5.438

33. Seralini GE, Cellier D, Spiroux de Vendômois J (2007) New analysis of a rat feeding study with a genetically modified maize reveals signs of hepatorenal toxicity. Arch Environ Contam Toxicol 52:596-602. https:// doi.org/10.1007/s00244-006-0149-5 
34. Spiroux de Vendômois J, Roullier F, Cellier D, Seralini GE (2009) A comparison of the effects of three GM corn varieties on mammalian health. Int J Biol Sci 5:706-726. https://doi.org/10.7150/ijbs.5.706

35. Spiroux de Vendômois J, Cellier D, Velot C, Clair E, Mesnage R, Seralini GE (2010) Debate on GMOs health risks after statistical findings in regulatory tests. Int J Biol Sci 6:590-598. https://doi.org/10.7150/ijbs.6.590

36. GMWatch (2019) ILSI exposed as industry lobby group. https://www. gmwatch.org/en/news/latest-news/18967-ilsi-exposed-as-industry-lobby -group. Accessed 15 Aug 2019

37. TestBiotech (2010) European Food Safety Authority: a playing field for the biotech industry. https://www.testbiotech.org/en/node/431. Accessed 15 Aug 2019

38. Weber S, Burtscher-Schaden H (2019) Detailed expert report on plagiarism and superordinated copy paste in the renewal assessment report
(RAR) on glyphosate. https://tinyurl.com/yxatq7e3. Accessed 15 Aug 2019

39. Lombart G (2019) OGM : ce que les Monsanto Papers révèlent du lobbying en France. Le Parisien 17 Jan. http://www.leparisien.fr/environnem ent/ogm-ce-que-les-monsanto-papers-revelent-du-lobbying-en-franc e-17-01-2019-7991310.php. Accessed 15 Aug 2019

40. Seralini GE (2019) CV Brief Seralini. http://www.seralini.fr. Accessed 15 Aug 2019

\section{Publisher's Note}

Springer Nature remains neutral with regard to jurisdictional claims in published maps and institutional affiliations.

\section{Submit your manuscript to a SpringerOpen ${ }^{\odot}$ journal and benefit from:}

- Convenient online submission

- Rigorous peer review

- Open access: articles freely available online

- High visibility within the field

- Retaining the copyright to your article

Submit your next manuscript at $\boldsymbol{\nabla}$ springeropen.com 